\title{
FECAL COLIFORM DISAPPEARANCE IN A RIVER IMPOUNDMENT
}

\author{
John J. Gaxinon*, Michael K. Busse and John E. Schillinger \\ Department of Environmental and Industrial Health. School of Public Health. The University of \\ Michigan, Ann Arbor, MI 48109, U.S.A
}

(Received January 1983)

\begin{abstract}
Fecal coliform (FC) disappearance studies were conducted in Ford Lake during the summer of 1979. Ford Lake, an artificial impoundment at the lower end of the Huron River drainage basin below Ypsilanti, Michigan, receives all upstream flow ( $2072 \mathrm{~km}^{2}$ of drainage). During dry weather an overall daytime FC disappearance rate of $0.4\left(\mathrm{~h}^{-1}\right)(K$ base e) was measured using dye tracer for timed collection. assuming a first order equation of the Chick type. Sedimentation was demonstrated as important in the overall FC disappearance in the upper end of the lake. Rooftop studies showed light level to affect daytime disappearance. Two types of wet weather conditions were documented: (1) where a substantial increase in How occurred due to an isolated upriver storm; and (2) as a result of two different storm events in the Ford Lake area itself. In both cases. Ford Lake was effective in substantially reducing the large FC contribution.
\end{abstract}

\section{INTRODUCTION}

During the summer of 1979, intensive fecal eoliform disappearance studies were conducted in Ford Lake, an impoundment of the Huron River, downstream from Ypsilanti, Michigan. Interest in fecal coliform levels exists because of the recreational use of the impoundment. Early investigations showed a significant fecal coliform disappearance in the upper end of the lake. Subsequent additional studies included fecal coliform measurements during dry period steady state flows using dye tracer for timed collection purposes, fecal coliform measurements during wet weather conditions, special outdoor rooftop recirculating flow system experiments, and investigations of the fecal coliform association with suspended particles and lake bottom sediments.

To describe declining bacterial densities, the term. disappearance will be used, for this term describes the generally observed phenomenon (which includes sedimentation. predation. dilution and death) without implying that any one factor (such as death) is wholly responsible. It is assumed that a first order equation of the Chick (1908) type describes disappearance, which can be expressed in the form:

$$
\frac{N_{1}}{N_{0}}=\mathrm{e}^{-k t}
$$

where $t=$ time, $n=$ number of organisms and $K=$ disappearance coefficient.

An extensive literature review on bacterial disappearance prepared by Burton and Gannon (1980) included the classic works of Chick (1908), Frost and Streeter (1924), Streeter (1934), Phelps (1944); the review articles of Berg et al. (1966), Rudolfs et al.,

\footnotetext{
*To whom all correspondence should be addressed.
}

(1950) and Kittrell and Furfari (1963); and the more recent works by Velz (1970) and Chamberlin and Mitchell (1978). The annual reviews by Geldreich $(1980,1981)$ have presented additional information on this topic.

Mitchell and Chamberlin (1978) presented a comprehensive review of the survival of indicator organisms, including a discussion of the collective influence of several significant factors. A table of field study results from ocean outfalls and one of freshwater die-off rates of coliform bacteria measured in situ were presented. For freshwater conditions the median $K$ value was $0.040\left(\mathrm{~h}^{-1}\right)$, with $60 \%$ less than $0.050\left(\mathrm{~h}^{-1}\right)$ and $90 \%$ less than $0.110\left(\mathrm{~h}^{-1}\right)$. Morrison and Fair (1966) reported on the influence of environment on stream microbial dynamics from a study on the Cache la Poudre River in Larimer County, Colorado. Gannon and Meier (1974) reported on in situ incubation studies conducted in Grand Traverse Bay, Michigan (an arm of Lake Michigan). They incubated various mixtures of Traverse City. Michigan raw sewage and Traverse Bay water in the bay using 5 gallon glass carboys. A pattern of temporary bacteral increase exceeding initial levels followed by rapid disappearance was observed for total and fecal coliforms. Zanoni and Fleissner (1982) observed a similar pattern in a study of indicator bacteria survival under laboratory conditions.

Kay and McDonald (1980) and McDonald and Kay (1981) reported on the behavior of coliform bacteria in two British upland storage reservoirs. Thornton et al. (1980) reported on storm events which were sampled in the Caddo River above DeGray Reservoir, Arkansas and then tracked through the reservoir using the increased turbidity associated with the storm flows. 


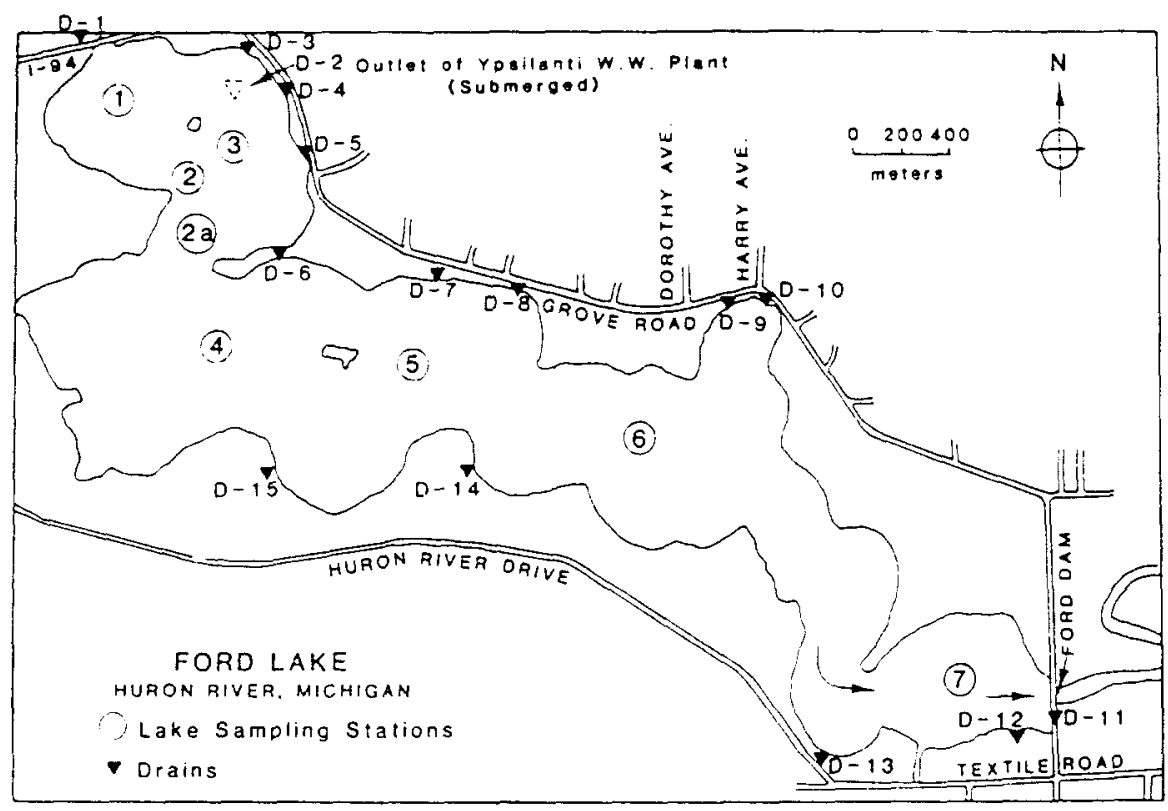

Fig. I. Location of lake sampling stations and drains.

The present study presents information on fecal coliform behavior in an instream impoundment located near the mouth of its drainage basin. involving both dry weather and wet weather situations. A number of water quality measurements were made-microbiological, physical and chemical-as part of the overall study. However, the primary focus of this presentation is on the fate of fecal coliform organisms in the Ford Lake impoundment.

\section{STUDY AREA}

Ford Lake is an artiticial impoundment at the lower end of the Huron River drainage basin, with all of the upstream river flow (drainage from about $2072 \mathrm{~km}^{2}$ ) passing through it. The lake has a surface area of about $3251.5 \times 10^{3} \mathrm{~m}^{2}$. a volume of about $15,151 \times 10^{9} \mathrm{~m}^{3}$, a length of about $3658 \mathrm{~m}$ and a mean depth of $4.66 \mathrm{~m}$. However, in the more active upper section of the lake. the mean depth ranges from 0.9 to $1.83 \mathrm{~m}$, where good mixing is observed with no thermal stratification. Figure I shows Ford Lake with the location of the lake sampling stations and storm drains used in this study. The Huron River enters the lake at the upper left and leaves at the lower right hand section of the figure. The impoundment. therefore, is a main river impoundment. initially developed for hydroelectric power generation. in contrast to the upland reservoirs described by Kay and McDonald (1980) and McDonald and Kay (1981).

In addition to the river flow. the chlorinated effluent from the Ypsilanti $0.22 \mathrm{~m}^{3} \mathrm{~s}^{-1}$ secondary wastewater treatment plant entered the upper end of the impoundment through a submerged outfall during the study. The How from this facility represented a small part of the total flow entering the impoundment. River flow entering the lake is meatsured by a continuously recording U.S. Geological Survey stream gage located on the Huron River in the City of Ypsilanti. Michigan. just upstream from Ford Lake.

Potential point and non-point upstream pollution sources include treated secondary effluent from the City of Ann Arbor. and the Villages of Dexter and Chelsea; urban non-point separate stormwater runoff from the cities of Ypsilanti and Ann Arbor: rural non-point runoff from agricultural sources. and possible discharge from non- functional individual septic systems. Some fourteen storm drains discharge directly into Ford Lake as shown in Fig. 1.

\section{PROCEDURES}

This investigation included two separate phases: (1) involving fecal coliform measurements during dry period steady state flows in Ford Lake, together with special outdoor rooftop recirculating flow system experiments, and investigations of the fecal coliform association with suspended particles and lake bottom sediments: and (2) fecal coliform measurements during wet weather conditions. Membrane filter techniques were used routinely for enumeration of fecal coliform as detailed in Standard Methods for the Examination of Water and Wastewater (APHA. 1976). On a few occasions, the Most Probable Number (MPN) technique was used for fecal coliforms.

\section{Dry weather periods}

Field bacterial disappearance investigations were conducted in Ford Lake, involving the addition of Rhodamine WT dye over a short period of time in the Huron River just before it enters the lake. and then following this dye mass through the lake using a sensitive fluorometer mounted in a boat. Samples were collected about $15 \mathrm{~cm}$ below the water surface for fecal coliform determination from the center of the dye mass at timed intervals as it moved through the upper end of the impoundment. Mitchell and Chamberlin (1978) have reviewed this procedure and discussed the advantages and possible limitations of the approach. These investigations were repeated on three separate days-1, 8 and 16 August 1979. In addition, more limited sampling took place during the summer of 1979 on several occasions to better define background dry weather fecal coliform levels in Ford Lake.

Laboratory bacterial disappearance studies paralleling field efforts were conducted on 1 and 8 August 1979 by collecting a water sample at the same Huron River site where the dye was added. at the same time as the start of a field disappearance investigation, then rapidly transporting the sample to the laboratory. Here an exposed outdoor recirculating flow system on the roof of the School of Public Health building was used as described by Cubbage et al. (1979). The disappearance experiment was initiated 
upon sample receipt, and resulting fecal coliform levels were determined on samples removed from the test system at frequent time intervals during subsequent daylight hours The velocity in the exposed tratys was low enough to allow sedimentation to occur. Using the rooftop sistem. the influence of natural light and low light conditions on Huron River water was examined. The low light condition was created by placing an opaque shield over the experimental tray. while the natural light tray was left uncovered and directly exposed to sunlight during the daytime period.

Another part of the study was investigation of the fecal colitorm association with suspended particles and lake bottom sediments. These considerations are important in the evaluation of the sedimentation component of the overall fecal coliform disappearance rate. Bacteria atre small and their settling rates are extremely slow. However, when they become attached to particulate matter, the sedimentation process can become more significant in overall disappearance.

The numbers of fecal coliforms attached to particulate matter in water samples were determined with the aid of tine nyton mesh screens (Nitex) having pore dimensions of 5,10 , 25.52 and $100 \mu \mathrm{m}$. together with the normal $0.45 \mu \mathrm{m}$ laboratory filter. A measured volume of sample was poured sequentially through the largest to the smallest screen filter. Each Nitex filter was aseptically removed from the filtration funnel after rinsing, rolled into a cylinder, and inserted into a $9 \mathrm{ml}$ blank of $\mathrm{PO}_{+}-\mathrm{MgSO}_{4}$ buffer containing 1 drop of Tween 80. This blank was then shaken vigorously for 1.5-2 min. Dilutions or portions of the suspension (in the $9 \mathrm{ml}$ blank) were filtered and incubated on standard MFC pads (APHA. 1976). The blue colonies were readily apparent even when solids covered the membrane surface. Subsequent adsorption control tests of a similar filtration system using pure cultures of E. coli, reported by Schillinger and Gannon (1982), showed approx. 0.2-5", of the bacteria added to be retained by the screens i.e. not going into suspension in the blank.

Attention was given to determining the fecal coliform concentrations in the like bottom sediments (top $2 \mathrm{~cm}$ ). particularly in the upper end of Ford Lake. A benthic microbe sampler was devised which utilized interchangeable sterile aluminum cylinders. One end of the cylinder was modified to operate as at one-way valve and the other was stoppered with a rubber cork. Air contained within the cylinder allowed little or no water to be collected with the mud sample. A sediment core was aseptically brought to the surface and the $10 \mathrm{p} 1.5 \mathrm{~cm}$ of mud was transported on ice to the laboratory where I gram was aseptically weighed out (after thoroughly mixing the sediment sample). The $1 \mathrm{~g}$ portion was suspended in a $9 \mathrm{ml}$ blank of Standard Methods $\mathrm{PO}_{3}-\mathrm{MgSO}_{4}$ buffer and shaken well. Aliquots were tested for fecal coliforms using the membrane technique with MFC saturated pads.

In calculating numbers of fecal coliforms per gram dry weight, an additional mud sample was weighed out, dried overnight at $105 \mathrm{C}$ and cooled in a dessicator. The ratio of wet weight/dry weight was used as a correction factor in converting to numbers of fecal coliforms per gram dry weight.

\section{Wet weather periods}

Two types of wet weather conditions were documented: (1) where a significant increase in Huron River flow occurred as a result of an isolated storm in the upper part of the river basin; and (2) as a result of two different storm events in the Ford Lake area itself.

Heavy rainfall in the upper part of the basin resulted in very high flow from the Huron River in to the impoundment on 12 July 1979. No significant flow occurred from the storm drains discharging into Ford Lake: thus, the high flow came only from the Huron River. Extensive water sampling of Ford Lake took place on 12, 13 and 16 July 1979 following this event.

The second wet weather condition documented was the result of two different storm events in the Ford Lake area itsell. one on 25 July 1979 and the other on 17 August 1979. In each case a baseline presurvey of the impoundment water was conducted betore the event. followed by eight sampling runs over a 3 day period after the storm. In addition. each storm drain discharging to the lake was sampled twice during the sturm, once shortly after discharge from the drain began (A) and once later during peak discharge (B).

Samples were promptly transported to the laboratory for processing. During the $25 \mathrm{July} 1979$ event laboratory testing included both fecal coliform and fecal streptococi analyses. while during the 17 August 1979 event only lecal coliform analyses were performed.

\section{RESLLTS AND DISCLSSIOY}

\section{Dry weather periods}

Ford Lake field FC disappearance measurements of 8 and 16 August 1979 were made under similar hydrologic conditions and FC discharge levels. and are therefore directly comparable. Unusual hydrologic conditions existed on 1 August 1979 and as a result, the field observations of this day are not comparable with those of 8 and 16 August 1979 and are not considered representative by the writers.

Figure 2 shows the results of the 16 August 1979 measurements. Dye study results and physical observation of adjacent weed beds showed the existence of a definite channel in the upper end of the embayment. An overall FC disappearance $K$ rate of $0.39\left(h^{-1}\right)$ was calculated from the water column FC measurements and corresponding times between sampling points. In addition, it is seen that the bottom sediment fecal colitorm concentration is increasing in the upper area

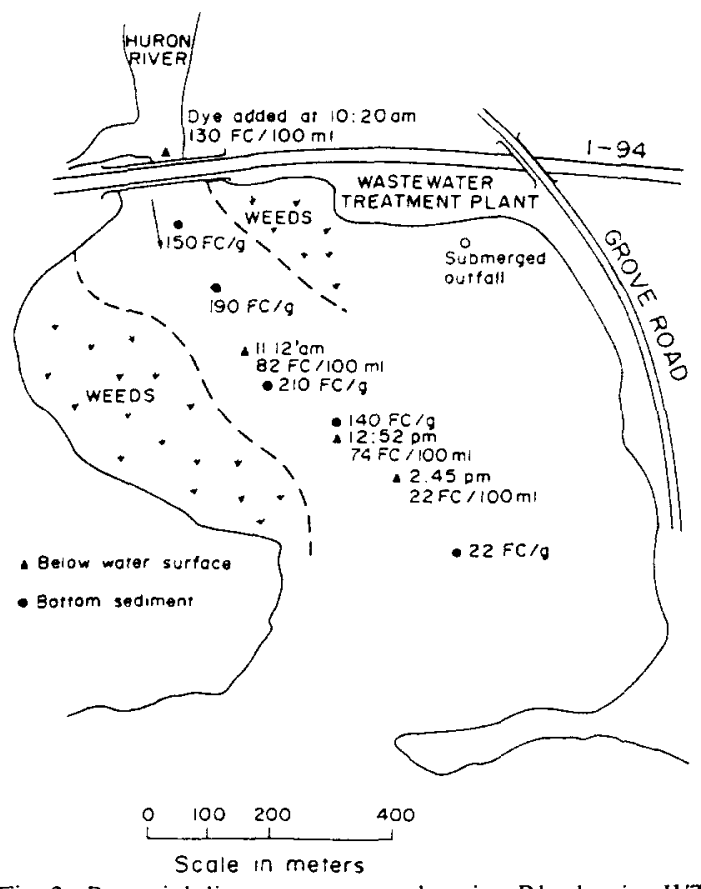

Fig. 2. Bacterial disappearance study using Rhodamine WT dye as a tracer-Ford Lake, 16 August 1979. 
Table 1. Fecal coliform disappearance rates $\alpha / h^{-1}$

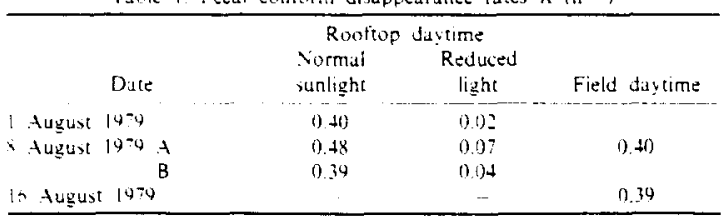

where the FC water column levels are decreasing. These observations strongly support the hypothesis that sedimentation of fecal coliform organisms attached to solid particles partially accounts for the high $\mathrm{FC}$ disappearance rate in this section of Ford Lake. In contrast, disappearance rates for other freshwater conditions have been reported by Mitchell and Chamberlin (1978) at a lower level of $0.1\left(\mathrm{~h}^{-1}\right)$ ( $K$ base e) or less. FC levels of Ford Lake water collected in the vicinity of the Ypsilanti wastewater plant submerged outfall were $<10 / 100 \mathrm{ml}$ indicating that during the 16 August 1979 survey, the FC contributions were coming from the Huron River. involving the various non-point and point sources previously presented.

Table 1 lists the FC disappearance rates under comparable daytime conditions for the field measurements of 8 and 16 August 1979, and the rooftop measurements of 1 and 8 August 1979. From the rooftop results it is seen that reduced light $K$ rates are substantially lower than the normal sunlight $K$ rates, indicating natural light level to have a substantial influence on FC disappearance rate. Also, it is seen that for 8 August 1979 , the field FC disappearance $K$ rate of $0.40\left(h^{-1}\right)$ is very close to the average rooftop normal sunlight rate of 0.48 and $0.39\left(\mathrm{~h}^{-1}\right)$. Such apparent $K$ rate agreement implies an ability of the rooftop system to simulate some Ford Lake conditions; a more definite statement requires further study.

Fecal coliform distribution according to particle size in upper Ford Lake water samples on 8 and 16 August 1979 using the fine nylon mesh screen apparatus are shown in Table 2. Ford Lake water samples provided low numbers of bacteria so that assessment of fecal coliforms in the different particle size catagories was difficult. The point where the river enters the lake (L-1) showed higher percentages of bacteria attached to particles (greater than $5 \mu \mathrm{m}$ in size) on both 8 and 16 August 1979, and the sites further down the impoundment ( $\mathrm{L}-2$ and $\mathrm{L}-2 \mathrm{a}$ ) appeared to show lower numbers of fecal coliforms in the larger particle size categories. This would be expected if the particles (with bacteria attached) were settling out as the river water moved through the embayment.

Higher concentrations of fecal coliforms in bottom sediments were observed in the upper part of Ford Lake in the channel where the Huron River flow is concentrated. Figure 2 shows that, along a transect (which is in the main flow channel), the bottom concentrations are highest in the middle part of the embayment channel and drop off in the lower end

\begin{tabular}{|c|c|c|c|c|}
\hline $\begin{array}{l}\text { Site } \\
\text { date }\end{array}$ & $0455 \mathrm{~m}$ & $525 \mathrm{Lm}$ & $25 \| н) u \mathrm{~m}$ & $>\{[i t\}\}_{\mu l} \mathrm{~m}$ \\
\hline $\begin{array}{l}\text { Ford L.1 } \\
(8 \text { Aug } 19-4)\end{array}$ & $\begin{array}{l}1911 \\
19 ! 30^{*}\end{array}$ & 9 & (1) & \\
\hline $\begin{array}{l}\text { Ford L-2 } \\
\qquad 8 \text { Aug } 19791\end{array}$ & $\begin{array}{c}35 \\
(9-6)\end{array}$ & 127 & $!$ & \\
\hline $\begin{array}{l}\text { Ford L-i } \\
\left(16 \text { tug. } 19^{-9}\right)\end{array}$ & $\begin{array}{l}36 \\
(91) .193\end{array}$ & 4 & (1) 0 & \\
\hline $\begin{array}{l}\text { Ford L.2 } \\
(16 \text { tug. }(9-9)\end{array}$ & $\begin{array}{c}3 \times 8 \\
19501\end{array}$ & $\therefore$ & (i) (i) & \\
\hline $\begin{array}{l}\text { Ford b.2d } \\
\qquad 16 \text { Aug. } 1979)\end{array}$ & $\begin{array}{c}27 \\
(96.0)\end{array}$ & $\begin{array}{c}1 \\
(+\infty)\end{array}$ & $\begin{array}{l}0 \\
\text { (1). } 0)\end{array}$ & \\
\hline
\end{tabular}

- Numbers in parentheses show " of the sum of numbers on the Nitex filter and 1$) .5 \mu \mathrm{m}$ membrane thiters

Dye tracer studies showed this to correspond to the end of the river channel influence, i.e. the flow there became dispersed in all directions. The Huron River has been found to provide a consistent loading during dry weather periods of fecal coliforms (approx. $100-300 / 100 \mathrm{ml}$ ) to upper Ford Lake from the various non-point and pont sources previously presented. The increase in bottom concentrations provide good evidence for the settling of bacteria in this part of the upper impoundment. The lower numbers found as one progresses through the embayment may reflect the decreased rate of sedimentation and longer exposure time in the lake environment. The lower parts of Ford Lake thus would be expected to have very low concentrations of fecal coliforms and this was observed

Fecal coliform concentrations of bottom sediments collected on 8 August 1979 using the Benthic Microbe sampler, followed a pattern similar to that observed on 16 August 1979.

\section{Wet weather periods}

The first wet weather condition documented resulted from very high flow from the Huron River into the impoundment on 12 July 1979. Figure 3 shows the 12 July 1979 flow to be comparable in magnitude to the usual high spring time flow.

Figure 4 shows the fecal coliform levels for the early afternoon of 12 July 1979. It was visually apparent in the field that the leading edge of the turbid water mass has reached the lower end of the upper section of Ford Lake, with fecal coliform concentrations as high as $5800 / 100 \mathrm{ml}$ in the water mass (turbidity $=155 \mathrm{NTU}$ ) and $18: 100$ (turbidity $=$ $3.2 \mathrm{NTU}$ ) to $50 / 100 \mathrm{ml}$ (turbidity $=7.1 \mathrm{NTU}$ ) in the lower section of Ford Lake beyond the leading edge of the plume. High turbidity was visually observed and documented in the area of high coliform levels. The major mass of 12 July was visually observed and documented to dissipate in the upper end of the lake by 16 July 1979, when the elevated fecal coliform levels had disappeared and the more usual summertime conditions were observed throughout the lake. Ford Lake was effective in containing the large fecal coliform contribution (estimated at $9.5 \times 10^{14}$ organisms) of $12 \mathrm{July}$ and did not allow excessive coliforms to impact downstream areas. The $9.5 \times 10^{14}$ 


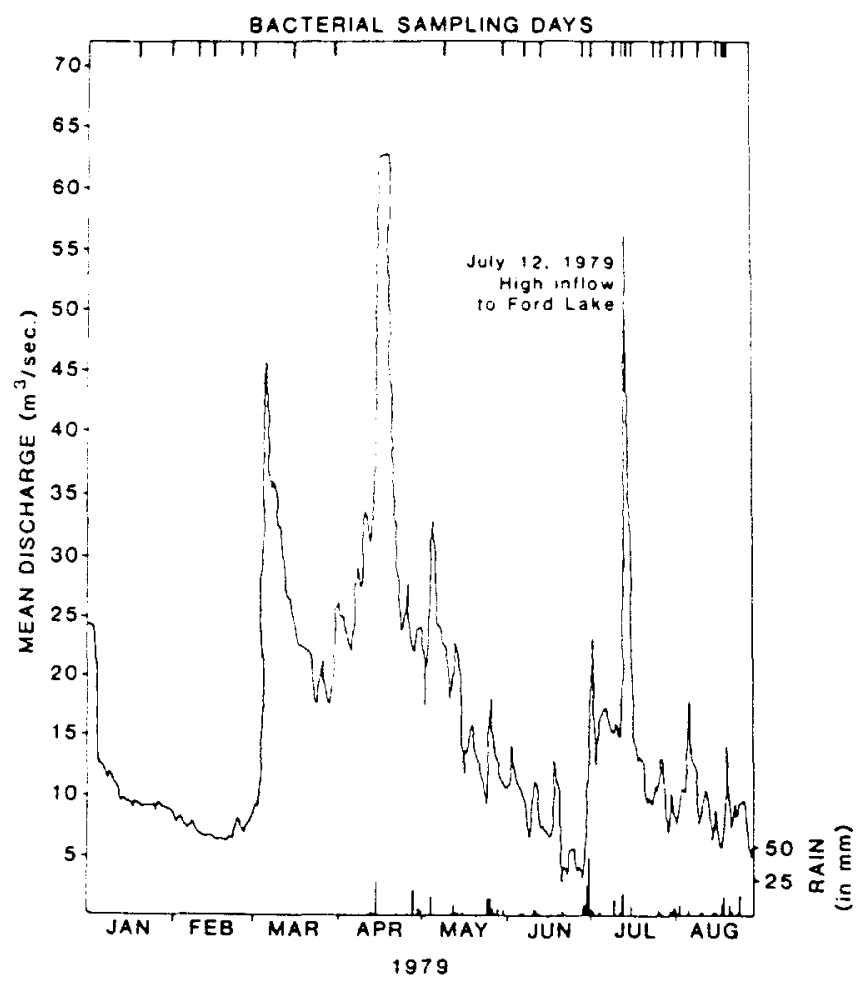

Fig. 3. Daily hydrograph, Huron River at Ypsilanti.

organism estimate was arrived at by taking the water mass above baseline flow measured at the Huron River Ypsilanti, Michigan, U.S.G.S. gage and multiplying it by an average fecal coliform concentration measured at the mouth of the Huron River where it discharges into Ford Lake. These observations might be compared to those of Thornton et al. (1980) for DeGray Reservoir, Arkansas where high disappearance rates in the upper end or entrance to a reservoir were observed.

The first intensive wet weather survey in the Ford
Lake area itself, where local stormwater was a significant contribution, was conducted during the period 24-27 July 1979. The results of the lake sampling are presented in Table 3 and the results of the drain sampling are presented in Tables 4 and 5 . The second survey, (Table 6 for the lake and Table 7 for the drains), following the same procedure as the first, was conducted during the period 17-20 August 1979. Fecal coliform disappearance was observed in both cases in the same upper end of the impoundment as it was during dry weather periods, and in neither

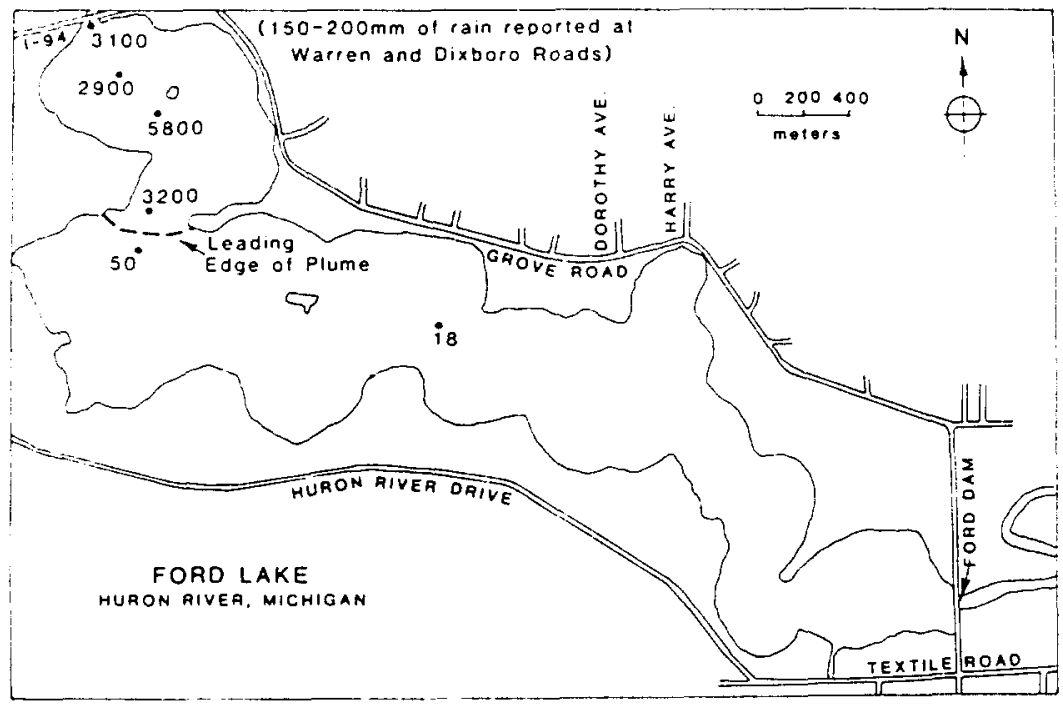

Fig. 4. Fecal coliforms in No./100 ml on 12 July 1979. 
Table 3. Wer weather evenc: lake survey 25 Juk 1079

\begin{tabular}{|c|c|c|c|c|c|c|c|c|c|}
\hline \multicolumn{10}{|c|}{ Fecial colitiorn (no. ml) } \\
\hline $\begin{array}{c}\text { Lixe } \\
\text { site }\end{array}$ & $A$ & B & $C$ & $\mathrm{D}$ & $E$ & $F$ & $G$ & $\mathrm{H}$ & 1 \\
\hline 1 & 290 & 650 & 690 & 290 & $\$ 70$ & 180 & 2011 & +71 & $+(t)$ \\
\hline ? & 180 & 600 & 1600 & $\$ 10$ & 710 & 200 & 70) & 200 & $20 t$ \\
\hline 3 & 5 & 1100 & 280 & 100 & 550 & 41) & 40 & $y_{0}$ & th \\
\hline 4 & 36 & 30 & 70 & $<2$ & 54 & 6 & 10 & $x$ & 6 \\
\hline 5 & I & 2 & 7 & 12 & 6 & 8 & 2 & 19 & h \\
\hline 6 & 2 & 2 & 15 & 21 & 20 & ? & 4 & 2 & 6 \\
\hline ? & l & 2 & 1 & 9 & 13 & 3 & $<?$ & $<2$ & $<1$ \\
\hline
\end{tabular}

\begin{tabular}{|c|c|c|}
\hline \multirow{2}{*}{$\begin{array}{l}\text { Drain } \\
\text { site }\end{array}$} & \multicolumn{2}{|c|}{$\begin{array}{l}\text { Fecal coliforms } \\
(\text { No. } \mathrm{ml})\end{array}$} \\
\hline & A & B \\
\hline 1 & 48.0000 & $4+000$ \\
\hline I* & 70 & 22.000 \\
\hline 3 & 5500 & 740 \\
\hline 4 & $1+000$ & 2701) \\
\hline 5 & 24,0000 & 1300 \\
\hline 6 & 24,000 & 14,000 \\
\hline 7 & 3.000 & 7900 \\
\hline 8 & 130,000 & 94,000 \\
\hline 9 & 2490 & $>1000$ \\
\hline 10 & 39,000 & 13,0100 \\
\hline 11 & 1300 & 1300 \\
\hline 12 & $11.00 \% 0$ & 31.0000 \\
\hline 13 & 16.000 & 7100 \\
\hline is & 21.000 & 32.000 \\
\hline 15 & 66000 & 9800 \\
\hline
\end{tabular}

\begin{tabular}{|c|c|c|}
\hline \multirow{2}{*}{$\begin{array}{l}\text { Drain } \\
\text { site }\end{array}$} & \multicolumn{2}{|c|}{$\begin{array}{l}\text { Fecisl streptencieci } \\
\text { (Ni) mal }\end{array}$} \\
\hline & + & $B$ \\
\hline$i$ & 110,000 & $120,(n)$ \\
\hline $2 *$ & $<(00)$ & $F 9(x)$ \\
\hline 3 & $+i,(9)(1)$ & $1 \geq(6) 00$ \\
\hline 4 & 20.610 & $17 .(x) x)$ \\
\hline 5 & $(0),(n) 1)$ & $20 .(1900)$ \\
\hline 6 & 35,000 & $31,(9) 0$ \\
\hline 7 & 57.0400 & $\mid \gamma .(1)(x)$ \\
\hline 8 & $(10,0000$ & 67.(1)(6) \\
\hline 9 & $19.0100)$ & 620000 \\
\hline 10 & 72.0011 & $55 .(600)$ \\
\hline il & $50(\mathrm{H})$ & $(t \times 1)(1)$ \\
\hline 12 & 95140 & 22.01000 \\
\hline 13 & $8.4(k) 10$ & $i+()(t)$ \\
\hline 14 & 70.6010 & 120,000 \\
\hline 15 & 10,0000 & 21.0000 \\
\hline
\end{tabular}

Table 6. Wet weather event: lake survey (17 August 1979)

\begin{tabular}{|c|c|c|c|c|c|c|c|c|c|}
\hline \multicolumn{10}{|c|}{ Fecal coliforms $\left(\mathrm{No}_{0} /(10) \mathrm{ml}\right)$} \\
\hline $\begin{array}{l}\text { Lake } \\
\text { site }\end{array}$ & A & B & C & $\mathrm{D}$ & E & $\mathrm{F}$ & G & $H$ & 1 \\
\hline 1 & 770 & $30(0)$ & 1200 & 40 & 270 & 170 & 320 & $2 \times 0$ & 360 \\
\hline 2 & 40 & 110 & 2000 & 390 & 570 & 180 & 80 & 6i) & +4 \\
\hline 3 & 4 & 19000 & 1900 & 960 & 530 & 40 & $<10$ & I) & 16 \\
\hline 4 & 8 & 64 & 160 & 36 & 74 & 30 & 14 & 4 & I \\
\hline 5 & $<1$ & 6 & 8 & 10 & 3 & 6 & 4 & 1 & 3 \\
\hline 6 & 2 & 4 & $<1$ & 1 & 3 & 8 & 2 & 2 & 2 \\
\hline 7 & 1 & $<1$ & $<1$ & 1 & 5 & 4 & 2 & 2 & 1 \\
\hline
\end{tabular}

\begin{tabular}{crr}
$\begin{array}{c}\text { Table 7. Wet weather event: drain survey } \\
(17 \text { August } 1979)\end{array}$ \\
\hline $\begin{array}{c}\text { Fecal coliform } \\
\text { Drain }\end{array}$ & A No./ml) \\
site & B \\
\hline 1 & 23.000 & 20.000 \\
$2 *$ & 30 & 130 \\
3 & 1900 & 1500 \\
5 & 8000 & 590 \\
8 & 200 & 9700 \\
9 & 2300 & 5300 \\
10 & 120.000 & 13.000 \\
11 & 3800 & 1600 \\
13 & 2100 & 1700 \\
14 & 9100 & 14.000 \\
15 & 6000 & 3000 \\
\hline Ypsilanti wastewater treatment plant \\
Outfall.
\end{tabular}

case was there a substantial increase in organism concentration in the lower end of the lake, notwithstanding the discharge of storm drains in the area.

The fecal coliform and fecal streptococci results of the drain survey of 25 July 1979 were summarized using log-normal probability paper as presented by
Velz (1970). The log mean fecal coliform level was $8800 / 100 \mathrm{ml}$ and $\log$ mean fecal streptococci level was $27,500 / 100 \mathrm{ml}$, resulting in a $\mathrm{FC} / \mathrm{FS}$ ratio of 0.32 . Geldreich and Kenner (1969), Geldreich (1970, 1972) has interpreted a FC FS ratio of less than 0.7 as strong evidence of predominantly non-human fecal contamination.

\section{SUMMARY A.ND CONCLUSIONS}

Ford Lake is an artificial impoundment at the lower end of the Huron River (Michigan) drainage basin, with all of the upstream river flow (drainage from about $2072 \mathrm{~km}^{2}$ ) passing through it. In addition, some fourteen storm drains discharge directly in to the lake.

Fecal coliform disappearance rates in the lake water during the day of $0.4\left(\mathrm{~h}^{-1}\right)$ ( $K$ base e) were measured in the upper end of Ford Lake during dry 
weather periods. Sedimentation was demonstrated to be an important element in the overall fecal coliform disappearance in the upper end of the lake. Rooftop studies showed light level to affect daytime disappearance.

Upstream storm runoff greatly increased bacterial loads to Ford Lake under heavy rain conditions on 12 July 1979. Notwithstanding this high pollutant loading. Ford Lake was effective in removing the large fecal coliform contribution.

Two intensive wet weather surveys involving local stormwater runoff in the Ford Lake area itself demonstrated elevated fecal coliform levels in the upper end of the lake. but showed little if any increase in the lower end of the lake, notwithstanding the discharge of storm driins in the area.

Acknowleclgement - This study was financed in part by a special grant from the State of Michigan to The University of Michigan.

\section{REFERENCES}

APHA (1976) Stardard Methods for the Examination of W'ater and Wastewater, 14th Edition, $1193 \mathrm{pp}$. American Public Health Association, New York.

Berg G.. Scarpino P. and Berman D. (1966) Survival of bacteria and viruses in natural waters. In Proceedings of the National Simposium on Water Quality Standards for Natural Waters, pp. 231-240. The University of Michigan, Ann Arbor, MI.

Burton A. and Gannon J. J. (1980) Literature reviewBacterial disappearance and related studies. In $A$ Study to Determine the Factors Affecting the Water Quality of the Ford Lake-Bellerille Lake System. Appendix C, pp. $\mathrm{Cl}-\mathrm{C} 35$. Great Lakes and Marine Water Center, The University of Michigan, Ann Arbor, MI.

Chamberlin C. E. and Mitchell R. (1978) A decay model for enteric bacteria in natural waters. In Water Pollution Microhislogy (Edited by Mitchell R.), Vol. 2, pp. 324-348. Wiley, New York.

Chick H. (1980) An investigation of the laws of disinfection. J. Hig. 8, 92-158.

Cubbage C. P., Gannon J. J., Cochran K. W. and Williams G. W. (1979) Loss of infectivity of poliovirus I in river water under simulated fièld conditions. Water Res. 13, $1091-1099$.

Frost H. W. and Streeter H. W. (1924) Bacteriological Studies. A Study of the Pollution and Natural Purification of the Ohio Riter. Public Health Bulletin No. 143. Section 6. United States Public Health Service.

Gannon J. J. and Meier P. G. (1974) Grand Traverse Bat water quality investigations. The University of Michigan Sea Grant Technical Report No. 38. Ann Arbor. MI.

Geldreich E. E. (1970) Applying bacteriological parameters to recreational water quality. J. Am. Wat. Whs Ass. 62 . 113.

Geldreich E. E. (1972) Buffalo Lake recreationial water quality: a study in bacteriological data interpretation. Water Res. 6, 913-924.

Geldreich E. E. (1980) Microbiology of water-literature review. J. Wat. Pollut. Control Fe'd. 52, 177+1800.

Geldreich E. E. (1981) Microbiology of water-literature review. J. Wat. Pollut. Control Fetl. 53, $108:-1098$.

Geldreich E. E. and Kenner B. A. (1969) Concepts of fecal streptococci in stream pollution. J. W'at. Pollut. Control Fed. 41, R336-R352.

Kay D. and McDonald A. (1980) Reduction of colitorm bacteria in two upland reservoirs: the significance of distance decay relationships. Water. Res. 14. 305-318.

Kittrell F. W. and Furfari S. A. (1963) Observations of coliform bacteria in streams. J. W'at. Pollut. Controt Fed. $35,1361-1385$.

McDonald A. and Kay D. (1981) Enteric bacterial concentrations in reservoir teeder streams: baseflow characteristics and response to hydrograph events. Water. Res. 15, 961-968.

Mitchell R. and Chamberlin C. (1978) Survival of indicator organisms. In Indicators of Viruses in Water and Food (Edited by Berg G.). pp. 15-37. Ann Arbor Science. Ann Arbor, MI

Morrison S. M. and Fair J. F. (1966) Intluences of environment on stream microbial dynamics. Hydrology Paper No. 13. Colorado State University, For Collins. CO.

Phelps E. B. (1944) Stream Sanitation. Wiley, New York

Rudolls W., Falk L. L. and Ragotzki R. A. (1950) Literature review on the occurrence and survival of enteric. pathogenic, and related organisms in soil, water, sewage, and sludges and on vegetation. I. Bacterial and virus diseases. Seriage Ind. Waste: 22, 1261-1281.

Schillinger J. E. and Gannon J. J. (1982) Coliform Altachment to Suspended Particles in Stormwater. School of Public Health. The University of Michigan. Ann Arbor. MI

Streeter H. W. (1934) A formulation of bacterial changes occurring in polluted water. Sewage Wk: J. 6, 208-233.

Thornton K. W., Nix J. F. and Bragg J. D. (1980) Coliform and Water Quality: Use of Data in Project Design and Operation. Water Resour. Bull. 16, 86-92.

Velz C. J. (1970) Applied Siream Sanitation. Wiley, New York.

Zanoni A. E. and Fleissner J. T. (1982) Indicator bacteria survival under laboratory conditions. $J$. Wat. Pollut. Control Fed. 54, 500-503. 